\title{
Article \\ Enhancement to Salt Stress Tolerance in Strawberry Plants by Iodine Products Application
}

\author{
Julia Medrano Macías 1,*, María Guadalupe López Caltzontzit ${ }^{1}$, Erika Nohemi Rivas Martínez ${ }^{2}$, \\ Willian Alfredo Narváez Ortiz ${ }^{1}$, Adalberto Benavides Mendoza ${ }^{1}$ and Paulino Martínez Lagunes ${ }^{3, *}$ \\ 1 Departament of Horticulture, Autonomous Agrarian University Antonio Narro, Calzada Antonio Narro, \\ 1920, Buenavista, Saltillo 25315, Mexico; lupitalopec@gmail.com (M.G.L.C.); \\ williamnarvaez@hotmail.com (W.A.N.O.); abenmen@uaaan.mx (A.B.M.) \\ 2 Departament of Botany, Autonomous Agrarian University Antonio Narro, Calzada Antonio Narro, 1920, \\ Buenavista, Saltillo 25315, Mexico; erika_rivas257@outlook.com \\ 3 Quimcasa de México, 16 de septiembre, 777, Alce blanco, Naulcapan, Estado de México, \\ Naucalpan de Juárez 53370, Mexico \\ * Correspondence: jmedmac@gmail.com (J.M.M.); paulinoml@gmail.com (P.M.L.); \\ Tel.: +52-811-8000182 (J.M.M.)
}

check for updates

Citation: Medrano Macías, J.; López Caltzontzit, M.G.; Rivas Martínez, E.N.; Narváez Ortiz, W.A.; Benavides Mendoza, A.; Martínez Lagunes, P. Enhancement to Salt Stress Tolerance in Strawberry Plants by Iodine Products Application. Agronomy 2021 11, 602. https://doi.org/10.3390/ agronomy11030602

Academic Editors:

Massimiliano D'Imperio,

Francesco Serio, Francesco Di Gioia,

Agnieszka Sẹkara and Carla

Sancho dos Santos

Received: 12 February 2021

Accepted: 18 March 2021

Published: 22 March 2021

Publisher's Note: MDPI stays neutral with regard to jurisdictional claims in published maps and institutional affiliations.

Copyright: (c) 2021 by the authors. Licensee MDPI, Basel, Switzerland. This article is an open access article distributed under the terms and conditions of the Creative Commons Attribution (CC BY) license (https:// creativecommons.org/licenses/by/ $4.0 /)$
Abstract: Iodine is a non-essential element for land plants, but is considered as a beneficial element, related to antioxidant capacity, environmental adaptations and improvement of plant growth. Salinity is one of the more recurrent abiotic stresses worldwide, seriously affecting vegetal production. The aim of this work was to evaluate iodine application (Q products ${ }^{\circledR}$ and $\mathrm{KIO}_{3}$, Quimcasa de México, Naucalpan, Mexico) in strawberry plants under normal and salt stress conditions. Growth, antioxidant content, essential minerals, iodine accumulation and fruit quality were evaluated. The results showed that, under stress conditions, the application of $Q$ products increased ascorbate peroxidase (APX) and catalase (CAT) activity as well as glutathione (GSH) content and yield in fruit, without avoiding biomass loss; with the application of $\mathrm{KIO}_{3}$ an increase in $\mathrm{GSH}$ and APX activity as well as $\mathrm{P}$ and $\mathrm{K}$ concentrations were obtained. In leaves an increase in $\mathrm{P}, \mathrm{Ca}, \mathrm{Mn}$ and iodine accumulation was evidenced with the application of $Q$ products, and an increased concentration of ascorbic acid and iodine with $\mathrm{KIO}_{3}$ treatments. Under normal conditions in fruits, the application of $\mathrm{Q}$ products increased phenolic compounds synthesis; additionally, an increase in Ca and $\mathrm{Mn}$ concentrations was shown. $\mathrm{KIO}_{3}$ application increased the firmness and $\mathrm{Mn}$. In leaves, the application of $\mathrm{Q}$ products increased chlorophyll $\mathrm{a}, \mathrm{b}$ and calcium. In conclusion, the application of iodine improves the quality value of strawberries under normal conditions and provides an enhancement of salt stress tolerance.

Keywords: antioxidants; nutraceuticals; redox metabolism; iodine

\section{Introduction}

Iodine is an essential trace element in mammals, but not for terrestrial plants. However, exogenous application of iodine in plants has been associated with beneficial effects, such as an increase in growth, increase in the biosynthesis of antioxidants and enhancement of tolerance stress [1]. However, the specific physiological mechanism via which this phenomenon occurs remains unclear, but is possible to attribute it to the broad oxidoreductive capacity of this element [2]. Related to the above, two functional hypotheses exist; the first one suggests a direct reaction between iodine in its reduced form and reactive oxygen species (ROS), acting as an inorganic antioxidant, most clearly evidenced in aquatic species such brown seaweed [3]; the second suggest that this element can act as a pro-oxidant, triggering a greater synthesis of antioxidants; an example of this is the positive correlation found between iodate and iodide application in crops such as tomato [4], lettuce [5], basil [6], pepper [7], grains [8], etc., and the increase in both enzymatic antioxidants such 
as superoxide dismutase and ascorbate peroxidase, as well as non-enzymatic antioxidants such as phenolic compounds, glutathione, and anthocyanins content, providing an increase in tolerance to adverse factors $[9,10]$.

The strawberry crop has an enormous economic importance around the world, due mainly its high nutritional value and flavor. Mexico has a planted area of 24,600 ha, being in third place worldwide in strawberry production, below only the United States and China [11].

Salinity is a major abiotic stress that restricts plant productivity caused by ionic and osmotic unbalance, affecting the metabolism, homeostasis and growth [12]. It is estimated that at least a third of agricultural land in the world is affected by high salt content [13]. Particularly, strawberry plants exhibit a great sensitivity to salinity [14], their optimum electrical conductivity (EC) being between 1 and $1.5 \mathrm{dS}$; values above these cause adverse effects on metabolism [15].

For that reason, the principal objective of this research work was to determine the effect of the application of iodine-based products, Q products (Q 2000 plus ${ }^{\circledR}, \mathrm{Q}$ irrigation ${ }^{\circledR}, \mathrm{Q}$ catalyst ${ }^{\circledR}$ and $Q$ energy ${ }^{\circledR}$, Quimcasa de México, Naucalpan, Mexico) and $\mathrm{KIO}_{3}$, on growth, antioxidant content, essential minerals, iodine accumulation and fruit quality, in order to establish if they provide enhancement against stress conditions.

\section{Materials and Methods}

\subsection{Plant Material and Growth Conditions}

On June 2019, strawberry plants cv San Andreas were planted in 10 L containers filled with loam soil + perlite $(1: 1 \mathrm{v} / \mathrm{v})$, with content of organic matter $4.9 \%$, C.E. $0.58 \mathrm{dS} \mathrm{m}^{-1}$, $\mathrm{pH}_{\text {(water) }} 7.59$ and the following concentration of available forms of nutrients was measured:

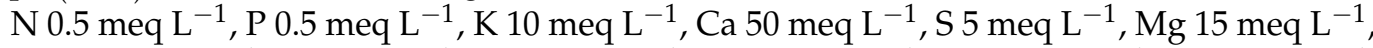
$\mathrm{Na} 7.54 \mathrm{meq} \mathrm{L}^{-1}$, Fe $4 \mathrm{mg} \mathrm{L}^{-1}$, Zn $1.8 \mathrm{mg} \mathrm{L}^{-1}, \mathrm{Mn} 8.7 \mathrm{mg} \mathrm{L}^{-1}, \mathrm{Cu} 0.5 \mathrm{mg} \mathrm{L}^{-1}$, B $0.76 \mathrm{mg} \mathrm{L}^{-1}$. Nutrition was applied one day after plant establishment by an automated irrigation system, starting with the application of humic acids at $3.8 \mathrm{Kg} \mathrm{ha}^{-1}$, continuing with nutritive solution containing $\mathrm{MgSO}_{4} 0.5$ meq L ${ }^{-1}, \mathrm{KNO}_{3} 5.65$ meq L ${ }^{-1} \mathrm{H}_{3} \mathrm{PO}_{4} 12.5 \mathrm{~mL}$ [16] and ending with citric acid at $15 \mathrm{~kg} \mathrm{ha}^{-1}$, rotating once per week. The pots were kept in a greenhouse in Saltillo, Coahuila, Mexico. During the experiment the average temperature was $21^{\circ} \mathrm{C}$ and relative humidity $51 \%$.

\subsection{Iodine Based Products Application and Salt Stress Conditions}

Application of iodine based products, via foliar, started one week after plantation (June 2019), until the end of the crops cycle (January 2020). These consisted of two sources of iodine: $\mathrm{KIO}_{3}$ (reagent grade) applied biweekly at $100 \mu \mathrm{M}$, and Q products ${ }^{\circledR}$ applied twice weekly in two different rounds, as indicated in Figure 1 and Table 1, under normal conditions (EC. $1.5 \mathrm{dS} \mathrm{m}^{-1}$ ). Salt stress started seven weeks after plantation applying $\mathrm{NaCl}$ $10 \mathrm{mM}$, reaching an electrical conductivity $(\mathrm{EC})$ of $2.5 \mathrm{dS} \mathrm{m}^{-1}$.

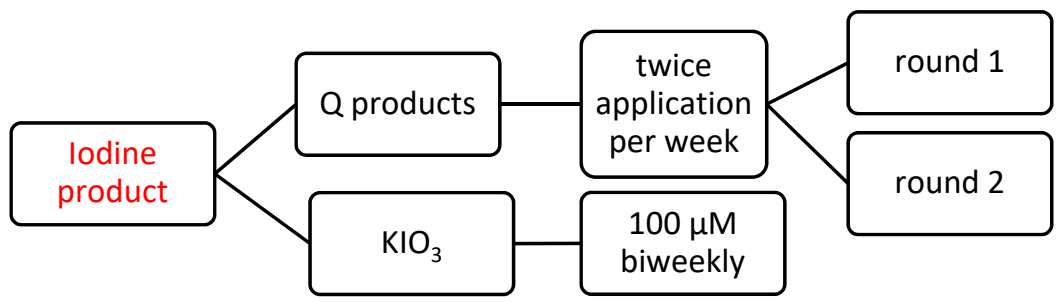

Figure 1. Graphical Scheme of $Q$ products treatment application frequency. 
Table 1. Q products ${ }^{\circledR}$ application frequency, in agreement with the commercial brand.

\begin{tabular}{|c|c|}
\hline Round 1. First application (Tuesday) & $\begin{array}{c}\text { Q } 2000 \text { Plus }{ }^{\circledR 7.5 ~ m L ~} \mathrm{~L}^{-1}, \mathrm{Q} \mathrm{Algy}^{\circledR} 7.5 \mathrm{~mL} \mathrm{~L}^{-1}, \mathrm{Q} \\
\operatorname{Riego}^{\circledR} 0.5 \mathrm{~mL} \mathrm{~L}^{-1}\end{array}$ \\
\hline Second application (Thursday) & Q 2000 Plus $^{\circledR} 7.5 \mathrm{~mL} \mathrm{~L}^{-1}$ \\
\hline Round 2. First application (next Tuesday) & $\begin{array}{c}\text { Q } 2000 \text { Plus }{ }^{\circledR} 7.5 \mathrm{~mL} \mathrm{~L}^{-1}, \mathrm{Q} \mathrm{Energy}^{\circledR} 7.5 \mathrm{~mL} \mathrm{~L}^{-1} \text {, } \\
\mathrm{Q} \mathrm{Riego}^{\circledR} 0.5 \mathrm{~mL} \mathrm{~L}^{-1}\end{array}$ \\
\hline Second application (next Thursday) & Q 2000 Plus ${ }^{\circledR} 7.5 \mathrm{~mL} \mathrm{~L}^{-1}$. \\
\hline
\end{tabular}

The reported composition of the Q 2000 plus product is 1.5\% free iodine, $10 \%$ catalysts, $27 \%$ surfactant, $61.5 \%$ vehicle. Q Algy extract of kelp and spirulina 22.1\%, Q energy: humic and fulvic acids 3\%, amino acids 7\%, macros $4-2-2 \%$, micros $12 \%$ and vehicle $78 \%$.

The experimental design was completely randomized and treatments were applied in plants with and without stress conditions, as shown in Table 2, every treatment with 25 repetitions giving a total of 150 strawberry plants.

Table 2. Representation of treatments applied under normal and stress conditions.

\begin{tabular}{ccc}
\hline Control & Q Products & $\mathrm{KIO}_{3}$ \\
\hline \multirow{3}{*}{$\mathrm{NaCl} 10 \mathrm{mM}$} & Normal conditions EC 1.5 dS m & \\
& Q products $+\mathrm{NaCl}$ & $\mathrm{KIO}_{3}+\mathrm{NaCl}$ \\
& Salinity stress conditions EC $2.5 \mathrm{dS} \mathrm{m} \mathbf{~}^{-\mathbf{1}}$ & \\
\hline
\end{tabular}

\subsection{Plant Sampling}

Three samplings were carried out to determine growth. The first was carried out at 12 weeks after plantation (wap), in seedling stage; the second was carried out at 19 wap, in the flowering stage and the third was carried out at 30 wap, during full fruit production. Sampling was done in a completely randomized way; five plants were taken from each treatment and the number of leaves, crowns, foliar area, and fresh and dry weight of leaves, stems and roots, as well as fruit weight, were measured non-destructively.

In the third sampling, additionally to growth, antioxidants, essential minerals $(\mathrm{N}, \mathrm{P}, \mathrm{K}$, $\mathrm{Ca}, \mathrm{Mg}, \mathrm{Fe}, \mathrm{Mn}, \mathrm{Cu}$ and $\mathrm{Zn}$ ), quality of fruit and iodine content in leaves and fruits were evaluated.

\subsection{Quantification of Plant Growth \\ Leaf area}

The leaf area was measured with a Li-Cor model $3000 \mathrm{~A}$ leaf area integrator with $0.1 \mathrm{~mm}^{2}$ resolution along the leaf blade, expressed in units of $\mathrm{cm}^{2}$.

Fresh weight

The plants were divided into stems, roots and leaves, then washed and drained and weighed using an OHAUS (Ohaus Inc., Parsippany, NJ, USA) digital scales, recording the fresh weight. Subsequently, they were placed in a drying oven for $48 \mathrm{~h}$ at a temperature of $70{ }^{\circ} \mathrm{C}$ and then weighed again, the dry weight recorded and expressed in grams.

Dry weight

The stems, roots and leaves were weighed after $48 \mathrm{~h}$ of drying, using a digital scale, recording the weight in grams.

\subsection{Determination of Antioxidants}

Phosphate buffer extraction

The sampled plant tissue was lyophilized and macerated with a mortar, then $100 \mathrm{mg}$ of pulverized tissue were weighed and placed in tubes, then $10 \mathrm{mg}$ of polyvinyl pyrrolidone, $2 \mathrm{~mL}$ of $0.1 \mathrm{M}$ phosphate buffer $\mathrm{pH} 7.2$ were added and sonicated for $10 \mathrm{~min}$; subsequently it was subjected to microcentrifugation at $12,000 \mathrm{rpm}$ for $10 \mathrm{~min}$ at $4{ }^{\circ} \mathrm{C}$, then the supernatant 
was collected and filtered with a nylon membrane [17]. Finally, it was diluted 1:15 with phosphate buffer.

Water-acetone extraction

Powder tissue was weighed $(100 \mathrm{mg})$ and placed in tubes, then $2 \mathrm{~mL}$ of the water: acetone solution was added in a 1:1 ratio. This was vortexed for $30 \mathrm{~s}$, then sonicated for $5 \mathrm{~min}$ and finally subjected to microcentrifugation at $4{ }^{\circ} \mathrm{C}$ at $12,500 \mathrm{rpm}$ for $10 \mathrm{~min}$. The supernatant was filtered and placed in an amber tube.

Ascorbic acid (Asa)

Ascorbic acid was quantified by liquid chromatography (HPLC), using the water: acetone extract, under the following chromatographic conditions: mobile phase $\mathrm{NaH}_{2} \mathrm{PO}_{4}$ $50 \mathrm{mM}$ pH 2.8: acetonitrile (80/20), flow $1 \mathrm{~mL} \mathrm{~min}^{-1}$, wavelength at $230 \mathrm{~nm}$, Aquasil C-18 column, in a run time of $16 \mathrm{~min}$ [18].

Total phenols (Phe)

Total phenolic compounds were quantified from the water:acetone extract, according to [19], using a Folin-Ciocalteu reagent. The results were expressed in grams of gallic acid/kg dry tissue.

Superoxide dismutase (SOD)

The quantification of SOD was carried out from the phosphate buffer extract, using a Cayman $^{\circledR} 7060002$ commercial kit (Cayman chemical company, Ann Arbor, MI, USA.). In principle, the oxidation of the WST (Water soluble tetrazolium salt) dye is formed by the superoxide ions by the whole xanthine $(\mathrm{XO})$ / xanthine $(\mathrm{X})$ oxidase. The inhibition in WST oxidation is attributed to the neutralization of superoxide radicals by SOD.

Total proteins

Total proteins were quantified according to the method established by Bradford [20], the units expressed in $\mathrm{g}$ proteins $\mathrm{kg}^{-1}$ dry tissue.

Ascorbate peroxidase (APX)

The activity of the APX enzyme was determined at room temperature $\left(25^{\circ} \mathrm{C}\right)$ and proceeded as follows: $0.1 \mathrm{~mL}$ of the biomolecules extract, $0.5 \mathrm{~mL}$ ascorbate at $10 \mathrm{mg} \mathrm{L}^{-1}$ and $1 \mathrm{~mL} 100 \mathrm{mM} \mathrm{H}_{2} \mathrm{O}_{2}$ were added to a centrifuge tube. After $5 \mathrm{~min}$ the reaction was stopped with $0.4 \mathrm{~mL}$ of $5 \%$ trichloroacetic acid. The ascorbate consumption rate was quantified at $266 \mathrm{~nm}$ by spectrophotometer uv-vis. The units of activity (IU) were expressed in (ppm ascorbate) $\mathrm{min}^{-1} /$ total proteins [21].

Catalase (CAT)

Catalase activity was quantified by spectrophotometry, carried out by measuring two reaction times, time $0 \mathrm{~min}$ (T0) and time $1 \mathrm{~min}$ (T1). The reaction mixture for the blank was prepared by adding $0.1 \mathrm{~mL}$ of the biomolecules extract, $1 \mathrm{~mL}$ of phosphate buffer $\mathrm{pH}$ 7.2 and $0.4 \mathrm{~mL}$ of $5 \%$ trichloroacetic acid, and the reaction mixture for $\mathrm{T} 0$ was prepared by adding $0.1 \mathrm{~mL}$ of extract of biomolecules, $1 \mathrm{~mL}$ of $100 \mathrm{mM} \mathrm{H}_{2} \mathrm{O}_{2}$ and, immediately afterwards $0.5 \mathrm{~mL}$ of the $5 \%$ acid. The same process was applied for T1, except that the $0.5 \mathrm{~mL}$ of $5 \%$ acid was applied after $1 \mathrm{~min}$ of reaction between the extract and peroxide. The reaction was carried out at room temperature, under constant stirring. Finally, the consumption of $\mathrm{H}_{2} \mathrm{O}_{2}$ was read at $270 \mathrm{~nm}$ in a uv-vis spectrophotometer. The units of activity (IU) were expressed in $\mathrm{mM} \mathrm{H}_{2} \mathrm{O}_{2} \mathrm{~min}^{-1} /$ total proteins [22].

Glutathione peroxidase (GPX)

GPX activity was measured using the modified method of [23]; $0.2 \mathrm{~mL}$ of the extract was placed in tube, plus $0.5 \mathrm{~mL}$ of $1 \mathrm{mM}$ reduced glutathione and $0.2 \mathrm{~mL}$ of $0.067 \mathrm{M}$ $\mathrm{Na}_{2} \mathrm{HPO}_{4}$, then $0.2 \mathrm{~mL}$ of $1.3 \mathrm{mM} \mathrm{H}_{2} \mathrm{O}_{2}$. This was allowed to react for $10 \mathrm{~min}$ and was stopped by adding $1 \mathrm{~mL}$ of $1 \%$ trichloroacetic acid. This mixture was then centrifuged at $3000 \mathrm{rpm}$ for $10 \mathrm{~min}$, and subsequently $0.48 \mathrm{~mL}$ of the supernatant were placed in another tube plus $2.2 \mathrm{~mL}$ of $0.32 \mathrm{M} \mathrm{Na}_{2} \mathrm{HPO}_{4}$ and $0.32 \mathrm{~mL}$ of $1 \mathrm{mM}$ of the 5.5 dithio-bis- 2 nitro benzoic acid (DTNB). This was read in a spectrophotometer at $412 \mathrm{~nm}$ [24]. 


\section{Glutathione (GSH)}

GSH quantification was carried out by placing $0.48 \mathrm{~mL}$ of buffer extract plus $2.2 \mathrm{~mL}$ $\mathrm{Na}_{2} \mathrm{HPO}_{4}$ at $0.32 \mathrm{M}$ and $0.32 \mathrm{~mL} 1 \mathrm{mM}$ DTNB. This was allowed to react for $15 \mathrm{~min}$ at room temperature. Finally, this mixture was read in a uv-vis spectrophotometer at $412 \mathrm{~nm}$. The results were expressed in mM. [25].

Total anthocyanins

For the extraction of anthocyanins, $100 \mathrm{mg}$ of lyophilized fruit were weighed and 2 $\mathrm{mL}$ of the extraction solution (ethanol/water/concentrated $\mathrm{HCl}$ ) were added in a 70:29:1 ratio. It was subjected to homogenization using the vortex and subsequently separated by centrifugation at $12,000 \mathrm{rpm}$ for $10 \mathrm{~min}$. The supernatant was read at $540 \mathrm{~nm}$ in a uv-vis spectrophotometer. The concentration was calculated with the following formula and the results expressed in equivalents of malvidin-3-glucoside [26].

$\mathrm{TA}=(\mathrm{A} 540 \mathrm{~nm})($ Pm of malvidin glucoside $)(1000) /($ dilution factor $) /($ molar extinction coefficient $)($ path $)$.

\section{Chlorophylls (Chlo)}

The chlorophyll content was quantified by the method proposed by [27]. $1 \mathrm{~g}$ of fresh plant material was weighed, homogenized in mortar, then $5 \mathrm{~mL}$ of $90 \%$ acetone were added. Additionally, $10 \mathrm{mg}$ of magnesium carbonate was added (to protect and stabilize the chlorophylls). Then $2 \mathrm{~mL}$ of the extract were taken and placed in a centrifuge tube and centrifuged for $5 \mathrm{~min}$ at $10,000 \mathrm{rpm}$ at $2{ }^{\circ} \mathrm{C}$ and the supernatant was extracted. Chlorophylls $a$ and $b$ were quantified by reading absorbances at 663 and $645 \mathrm{~nm}$, respectively, and 90\% acetone was used as a blank. The total chlorophyll content was expressed as $\mu \mathrm{g} \mathrm{g}^{-1}$, and was determined using the following formulas.

$$
\begin{gathered}
\text { Chlorophyll a }\left(\mu \mathrm{g} \cdot \mathrm{g}^{-1}\right)=25.38 \times \mathrm{A} 663+3.64 \times \mathrm{A} 645 \\
\text { Chlorophyll b }\left(\mu \mathrm{g} \cdot \mathrm{g}^{-1}\right)=30.38 \times \mathrm{A} 645-6.58 \times \mathrm{A} 663 \\
\text { Chlorophyll total }\left(\mu \mathrm{g} \cdot \mathrm{g}^{-1}\right)=18.8 \times \mathrm{A} 663+34.02 \times \mathrm{A} 645
\end{gathered}
$$

\subsection{Determination of Essential Minerals}

Acid digestion of plant tissue

Dehydrated samples were weighted $(1 \mathrm{~g})$ and placed in beakers, then $30 \mathrm{~mL}$ of nitric acid were added for a period of $4 \mathrm{~h}$ on a heating plate until the clarification of the mixture. Finally, it was graded with distilled water to $100 \mathrm{~mL}$ and filtered with Whatman \# 41 paper [28].

\subsection{Quantification of Minerals}

The $\mathrm{K}, \mathrm{Ca}, \mathrm{Mg}, \mathrm{Mn}, \mathrm{Fe}, \mathrm{Zn}$ and $\mathrm{Cu}$ were quantified using a Varian spectra-240 fs (Agilent technologies, Inc., Santa Clara, CA, USA) atomic absorption spectrophotometer (AA) with flame. Phosphorus (P) was analyzed by uv-vis spectrophotometer, following the amino-naphthol-sulfonic acid (ANSA) technique according to [29]. Results of macroelements were reported in \% (g element $/ 100 \mathrm{~g}$ plant tissue) and microelements in ppm (mg element $/ \mathrm{kg}$ plant tissue).

\subsection{Quantification of Iodine Concentration}

Iodine was extracted from leaves and fruits using the alkaline ash technique modified by [30]; $1 \mathrm{~g}$ of dry plant tissue was weighed and placed in crucibles at constant weight. Later $2 \mathrm{~mL} 2 \mathrm{M} \mathrm{KOH}$ and $1 \mathrm{~mL}$ of $2 \mathrm{M} \mathrm{KNO}_{3}$ were added and the mixture placed in an oven at $100{ }^{\circ} \mathrm{C}$ for $2 \mathrm{~h}$. Subsequently, the crucibles were put in a muffle at $580{ }^{\circ} \mathrm{C}$ for $3 \mathrm{~h}$. Finally, the iodine was extracted with $2 \mathrm{~mL}$ of $\mathrm{KOH}$ at $2 \mathrm{mM}$. Quantification was performed using inductively coupled plasma-optical emission spectrometry (ICP-OES), Agilent 725. The results were expressed in $\mathrm{mg}$ I per $\mathrm{kg}$ of dry tissue. 


\subsection{Fruit Quality}

Firmness

The firmness of the strawberry fruits was measured with a GY-03 penetrometer. At an opposite point, the fruit was firmly grasped and the single-impulse penetrometer was introduced up to the mark, the reading was taken and the results obtained in $\mathrm{kg} / \mathrm{cm}^{2}$.

Brix grades

This measurement was made with the use of a manual refractometer, placing a drop of strawberry fruit juice and closing the lid gently so that the sample covered the surface of the prism; observing through the sight glass, the reading was taken directly and reported in o brix.

$\%$ Loss of Firmness

For this analysis firmness was measured as previously described and this was repeated after 7 days. To calculate the \% loss of firmness the following formula was used:

$\%$ loss of firmness $=($ firmness day $1-$ firmness day 7$) /(($ firmness day 1$) \times 100)$

\subsection{Fruit Production}

The harvest was collected according to the maturity of the fruit, determined by the color according to the Source: NMX-FF-062-SCFI-2002; all the fruits were harvested at the maturity stage chosen in each of the cuts that were made during the whole productive cycle; labeled according to the treatment and the plant number, they were weighed in a semi-analytical scale, and results reported in grams per plant.

\subsection{Statistical Analysis}

The statistical analysis was carried out in two forms, univariate and multivariate. Univariate was performed using an analysis of variance one way (ANOVA) with 5 repetitions per treatment. Each plant was considered as an experimental unit, followed by a test of means of least significant difference (LSD, $p<0.05$ ). For multivariate, a multiple linear regression was performed with Pearson correlation and principal components analysis (PCA) obtained from the correlation matrix, thus reducing the dimensionality of the database, both analyses using the Infostat software package (2018 version).

\section{Results}

\subsection{Growth Parameters-Anova One Way}

As can be seen in Figure 2, the harmful effect of salinity stress was evidenced in the second and third sampling through the reduction of biomass, by $26 \%$ and $16.7 \%$, respectively; the red arrows indicate the control plants and $\mathrm{NaCl}$ control.

The results indicated that under normal conditions the application of iodine-based products did not affect the plant biomass in any of the three samplings, compared with control. On the other hand, under salt conditions in the first and third sampling there were were no differences between the biomass of the treated and the control plants; however, in the second sampling the applications with Q products ${ }^{\circledR}$ (Quimcasa de México, Naucalpan, Mexico) showed a reduction in biomass, compared with control.

Table 3 shows results for growth parameters, number of leaves, crowns, leaf area (LA), fresh weight of leaves (FWL), stem (FWS) and root (FWR), as well as the total fresh weight (TFW) of the treated and control plants. It was found that the number of leaves, the number of crowns, the foliar area, and the fresh weight of the stem and leaves were not modified by any treatment or by saline stress. However, the reduction in fresh weight of the root, as well as of total fresh by the application of both sources of iodine under normal conditions and under conditions of salinity stress did not show statistically significant differences compared to the $\mathrm{NaCl}$ control plants. 


\section{Plant Biomass in three samplings}

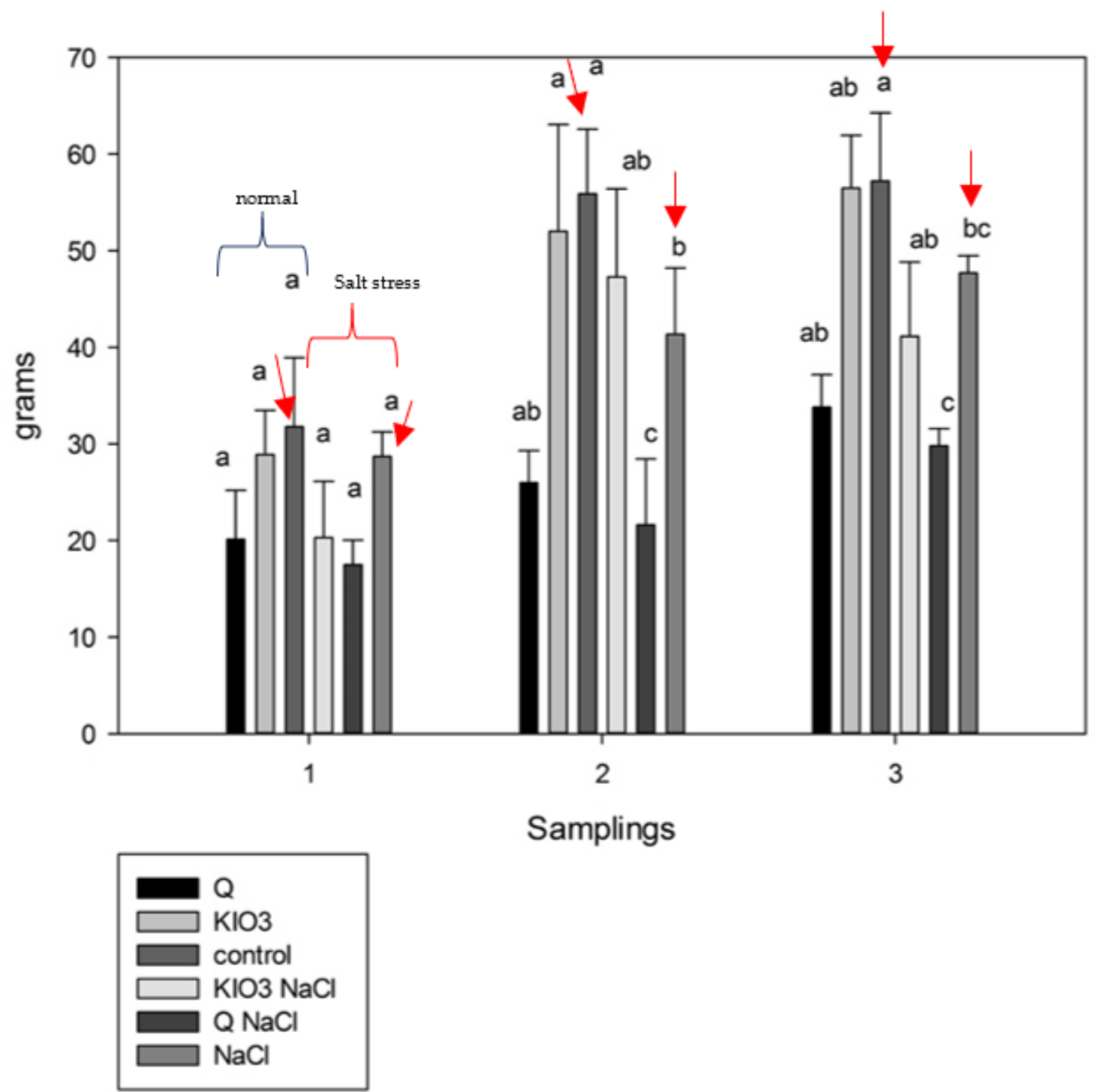

Figure 2. Total dry biomass of the strawberry plants treated with iodine-based products, represented in grams, in the three samplings under normal and salt stress conditions. Values with same letters do not show statistically significant differences, $p \geq 0.05$.

Table 3. Growth parameters in strawberry plant in third sampling.

\begin{tabular}{cccccccc}
\hline Treatment & $\begin{array}{c}\text { Number of } \\
\text { Leaves }\end{array}$ & $\begin{array}{c}\text { Numbers of } \\
\text { Crowns }\end{array}$ & $\begin{array}{c}\text { Leaf Area } \\
\text { (LA) }\end{array}$ & $\begin{array}{c}\text { Fresh Weight } \\
\text { of Leaves } \\
\text { (FWL)(g) }\end{array}$ & $\begin{array}{c}\text { Fresh Weight } \\
\text { of Stem } \\
\text { (FWS)(g) }\end{array}$ & $\begin{array}{c}\text { Fresh Weight } \\
\text { of Root } \\
\text { (FWR) (g) }\end{array}$ & $\begin{array}{c}\text { Fresh Weight } \\
\text { Total FWT (g) }\end{array}$ \\
\hline $\mathrm{Q}$ & $43.6 \mathrm{a}$ & $7.4 \mathrm{~b}$ & $13.47 \mathrm{a}$ & $46 \mathrm{a}$ & $38 \mathrm{a}$ & $44.3 \mathrm{~b}$ & $128.68 \mathrm{~b}$ \\
$\mathrm{KIO}_{3}$ & $62 \mathrm{a}$ & $13 \mathrm{a}$ & $14.91 \mathrm{a}$ & $54 \mathrm{a}$ & $44 \mathrm{a}$ & $58.5 \mathrm{~b}$ & $157.76 \mathrm{~b}$ \\
$\mathrm{KIO}_{3}+\mathrm{NaCl}$ & $55 \mathrm{a}$ & $8.4 \mathrm{a}$ & $12.9 \mathrm{a}$ & $46 \mathrm{a}$ & $36 \mathrm{a}$ & $54.4 \mathrm{~b}$ & $137.71 \mathrm{ab}$ \\
$\mathrm{Q}+\mathrm{NaCl}$ & $46.4 \mathrm{a}$ & $8.2 \mathrm{a}$ & $13 \mathrm{a}$ & $40 \mathrm{a}$ & $35 \mathrm{a}$ & $34.2 \mathrm{~b}$ & $109.93 \mathrm{~b}$ \\
control & $63.6 \mathrm{a}$ & $11.2 \mathrm{ab}$ & $11.3 \mathrm{a}$ & $69 \mathrm{a}$ & $52 \mathrm{a}$ & $71.33 \mathrm{a}$ & $192.9 \mathrm{a}$ \\
$\mathrm{NaCl}$ & $66.4 \mathrm{a}$ & $11 \mathrm{ab}$ & $13.6 \mathrm{a}$ & $58 \mathrm{a}$ & $63 \mathrm{a}$ & $58.1 \mathrm{~b}$ & $160.23 \mathrm{~b}$ \\
\hline
\end{tabular}




\subsection{Antioxidants}

\subsubsection{Fruits}

Table 4 show the results obtained for antioxidant content in strawberry fruits under normal and stress conditions. Regarding the concentration of ascorbic acid, modifications were not found by any treatment, with or without salinity stress. Total protein content decreased with the application of $Q$ products in both conditions, as well as plants under stress and treated with $\mathrm{KIO}_{3}$. Regarding the antioxidant activity of the main enzymes, it was evidenced that SOD did not show statistically significant differences between treatments, with and without conditions. However, the ascorbate peroxidase and catalase activity increased after the application of $Q$ products under stress conditions.

An increase in GPX activity was presented in plants under saline stress without treatments, a phenomenon that did not occur in plants under the same stress conditions treated with any of the iodine products. Consistent with the above, a reduction in the glutathione concentration was found in the $\mathrm{NaCl}$ control plants, as well as an increase in GSH after the application of both sources of iodine under salt stress.

No differences were observed between control and treated plants under normal conditions.

The content of total anthocyanins decreased with $\mathrm{KIO}_{3}$ treatment in comparison with the absolute control and $\mathrm{NaCl}$ control plants.

The antioxidant capacity did not show changes between treatments or stress conditions.

\subsubsection{Leaves}

Table 5 shows the results obtained from antioxidants and metabolites in leaves under normal and salt stress conditions, and it was found that after $Q$ products application the content of chlorophyll $\mathrm{a}, \mathrm{b}$ and total increased under normal conditions compared with the control. However, the same trend was found in the $\mathrm{NaCl}$ control plants. After application of $\mathrm{KIO}_{3}$ a reduction in total phenolic compounds was also evidenced. Under salt stress conditions it was found that, for the plants treated with $\mathrm{KIO}_{3}$, the content of ascorbic acid increased, while plants treated with Q products showed a reduction in GSH content.

\subsection{Essential Minerals}

\subsubsection{Fruits}

Table 6 shows the results of essential macro elements, expressed in \% (g mineral/100 g dry tissue) and microelements expressed in ppm $\left(\mathrm{mg} \mathrm{kg}^{-1}\right)$ in the fruits of strawberry plants under normal and stress conditions. Salinity stress led to a reduction in the concentration of potassium and magnesium, but $\mathrm{K}$ deficiencies were reduced after the application of both sources of iodine $\left(\mathrm{KIO}_{3}\right.$ and $\mathrm{Q}$ products) and for magnesium only with the application of $\mathrm{Q}$ products. A higher phosphorus concentration was also found after the application of $\mathrm{KIO}_{3}$ under salinity conditions compared to both controls. Additionally, the calcium concentration was increased with the application of $\mathrm{Q}$ products with and without salt stress. Finally, both iodine treatments promoted an increase in manganese content under normal conditions, no differences found in iodine concentration. 
Table 4. Effect of iodine- based products on antioxidants content in strawberry fruits, with and without salt stress.

\begin{tabular}{|c|c|c|c|c|c|c|c|c|c|c|c|}
\hline & Stress & Asa $\mathrm{g} \mathrm{kg}^{-1}$ & Prot $\mathrm{g} \mathrm{kg}^{-1}$ & Phe $\mathrm{g} \mathrm{kg}^{-1}$ & $\begin{array}{c}\text { Superoxide } \\
\text { Dismutase } \\
\text { (SOD) }\left(\mathrm{UI} \mathrm{g}^{-1}\right)\end{array}$ & $\begin{array}{l}\text { Ascorbate } \\
\text { Peroxidase } \\
\text { (APX) (UI) }\end{array}$ & $\begin{array}{l}\text { Catalase } \\
\text { CAT [UI] }\end{array}$ & $\begin{array}{l}\text { Glutathione } \\
\text { Peroxidase } \\
\text { (GPX) (UI) }\end{array}$ & $\begin{array}{l}\text { Glutathione } \\
\text { (GSH) (mM) }\end{array}$ & $\begin{array}{c}\text { Anthocy } \\
\left(\mathrm{mg} 100 \mathrm{~g}^{-1}\right)\end{array}$ & $\begin{array}{c}\text { Antioxid } \\
\text { Capacity } \\
\text { (mM Teac) }\end{array}$ \\
\hline Q & Without & $2.26 \mathrm{a}$ & $3.38 \mathrm{~b}$ & $2.28 \mathrm{a}$ & $6.23 a$ & $0.11 \mathrm{~b}$ & $33.9 \mathrm{~b}$ & $75.7 \mathrm{~b}$ & $0.38 \mathrm{ab}$ & $48.8 \mathrm{a}$ & $3 a$ \\
\hline \multirow{2}{*}{$\mathrm{KIO}_{3}$} & Without & $1.91 \mathrm{a}$ & $4.82 \mathrm{a}$ & $0.94 \mathrm{~b}$ & $3.93 \mathrm{a}$ & $0.31 \mathrm{~b}$ & $14.98 \mathrm{~b}$ & $46.1 \mathrm{~b}$ & $0.39 \mathrm{ab}$ & $30.1 \mathrm{~b}$ & $2.91 \mathrm{a}$ \\
\hline & $\mathrm{NaCl}$ & $2.21 \mathrm{a}$ & $3.07 \mathrm{~b}$ & $1.11 \mathrm{~b}$ & $6.3 \mathrm{a}$ & $0.07 b$ & $12.8 \mathrm{~b}$ & $73.7 \mathrm{~b}$ & $0.45 \mathrm{ab}$ & $58.3 \mathrm{a}$ & $2.97 \mathrm{a}$ \\
\hline control & Without & $1.75 \mathrm{a}$ & $4.11 \mathrm{a}$ & $1.06 \mathrm{~b}$ & $4 \mathrm{a}$ & $0.24 \mathrm{~b}$ & $19.66 \mathrm{~b}$ & $50.1 \mathrm{~b}$ & $1.46 \mathrm{a}$ & $48.7 \mathrm{a}$ & $2.94 \mathrm{a}$ \\
\hline
\end{tabular}

Values with same letters do not show statistically significant differences, $p \geq 0.05$ and in bold, are indicated the maximum and minimum statistically significant differences.

Table 5. Effect of iodine- based products on antioxidants content in leaves, with and without salt stress.

\begin{tabular}{|c|c|c|c|c|c|c|c|c|c|c|c|c|}
\hline & Stress & Asa $\mathrm{g} \mathrm{kg}^{-1}$ & Prot $\mathrm{g} \mathrm{kg}^{-1}$ & Phe $\mathrm{g} \mathrm{kg}^{-1}$ & $\begin{array}{c}\text { Superoxide } \\
\text { Dismutase } \\
\text { (SOD) }\left(\mathrm{UI} \mathrm{g}^{-1}\right)\end{array}$ & $\begin{array}{c}\text { Ascorbate } \\
\text { Peroxidasse } \\
\text { (APX) (UI) }\end{array}$ & $\begin{array}{l}\text { Catalase } \\
\text { (CAT) (UI) }\end{array}$ & $\begin{array}{l}\text { Glutathione } \\
\text { Peroxidase } \\
\text { (GPX) (UI) }\end{array}$ & $\begin{array}{c}\text { Glutathione } \\
\text { (GSH) } \\
\text { (mM) }\end{array}$ & $\begin{array}{c}\text { Chlo t } \\
\left(\mu g \cdot g^{-1}\right)\end{array}$ & $\begin{array}{c}\text { Chlo a } \\
\left(\mu g \cdot g^{-1}\right)\end{array}$ & $\begin{array}{c}\text { Chlo b } \\
\left(\mu g \cdot g^{-1}\right)\end{array}$ \\
\hline \multirow{2}{*}{$\mathrm{Q}$} & Without & $1.41 \mathrm{~b}$ & $3.1 \mathrm{a}$ & $7.7 \mathrm{ab}$ & $7.6 \mathrm{a}$ & $0.28 \mathrm{ab}$ & $40.7 \mathrm{a}$ & $94.7 \mathrm{a}$ & $1.11 \mathrm{ab}$ & 127.44 a & 77 a & $45.2 \mathrm{a}$ \\
\hline & $\mathrm{NaCl}$ & $1.48 \mathrm{~b}$ & $4.1 \mathrm{a}$ & $9.05 \mathrm{a}$ & $6 a$ & $0.88 \mathrm{a}$ & $41.6 \mathrm{a}$ & $63.44 \mathrm{a}$ & $0.73 b$ & $115.73 b$ & $76.1 \mathrm{~b}$ & $37.8 \mathrm{~b}$ \\
\hline \multirow{2}{*}{$\mathrm{KIO}_{3}$} & \multirow{2}{*}{ WithoutNaCl } & $0.47 \mathrm{~b}$ & $4.6 \mathrm{a}$ & $5.8 \mathrm{c}$ & $4 \mathrm{a}$ & $0.69 \mathrm{ab}$ & $15.5 \mathrm{a}$ & $50.12 \mathrm{a}$ & $1.06 \mathrm{ab}$ & $114.9 \mathrm{~b}$ & $75.9 \mathrm{~b}$ & $35.9 \mathrm{~b}$ \\
\hline & & $1.6 \mathrm{a}$ & $5.1 \mathrm{a}$ & $6.2 \mathrm{c}$ & $3.5 \mathrm{a}$ & $0.18 \mathrm{a}$ & $15.9 \mathrm{a}$ & 39.8 & $1.09 \mathrm{ab}$ & $113.3 \mathrm{~b}$ & $75.5 \mathrm{~b}$ & $33.08 \mathrm{~b}$ \\
\hline control & WithoutNaCl & $1.16 \mathrm{~b}$ & $4.3 \mathrm{a}$ & $9.2 \mathrm{a}$ & $4.3 \mathrm{a}$ & $0.78 \mathrm{a}$ & $10.5 \mathrm{a}$ & $70.7 \mathrm{a}$ & $1.36 \mathrm{a}$ & $100.89 \mathrm{~b}$ & $74.7 \mathrm{~b}$ & $26.36 \mathrm{~b}$ \\
\hline
\end{tabular}

Values with same letters do not show statistically differences, $p \geq 0.05$, and in bold, are indicated the maximum and minimum statistically significant differences. 
Table 6. Effect of iodine- based products on minerals content in fruits with and without salt stress.

\begin{tabular}{cccccccccccc}
\hline & \multicolumn{1}{c}{ Macroelements (\%) } & \multicolumn{4}{c}{ Microelements (ppm) } \\
\cline { 2 - 11 } & Stress & $\mathbf{P}$ & $\mathbf{K}$ & $\mathbf{N a}$ & $\mathbf{M g}$ & $\mathbf{C a}$ & $\mathbf{Z n}$ & $\mathbf{C u}$ & $\mathbf{F e}$ & $\mathbf{M n}$ & $\mathbf{I}$ \\
\hline \multirow{2}{*}{$\mathrm{Q}$} & Without & $0.20 \mathrm{~b}$ & $1.56 \mathrm{a}$ & $0.02 \mathrm{c}$ & $0.15 \mathrm{a}$ & $\mathbf{0 . 1 3} \mathbf{a}$ & $6.0 \mathrm{~b}$ & $8.4 \mathrm{a}$ & $25 \mathrm{a}$ & $\mathbf{1 4} \mathbf{a}$ & $4.08 \mathrm{a}$ \\
& $\mathrm{NaCl}$ & $0.3 \mathrm{~b}$ & $\mathbf{1 . 7 3} \mathbf{a}$ & $\mathbf{0 . 0 6} \mathbf{a}$ & $\mathbf{0 . 1 5} \mathbf{a}$ & $\mathbf{0 . 1 2} \mathbf{a}$ & $8.3 \mathrm{ab}$ & $5.6 \mathrm{a}$ & $0 \mathrm{a}$ & $13 \mathrm{ab}$ & $5.45 \mathrm{a}$ \\
\hline \multirow{2}{*}{$\mathrm{KIO}_{3}$} & Without & $0.24 \mathrm{~b}$ & $1.17 \mathrm{~b}$ & $0.02 \mathrm{c}$ & $0.13 \mathrm{a}$ & $0.09 \mathrm{bc}$ & $9.4 \mathrm{ab}$ & $2.9 \mathrm{a}$ & $19 \mathrm{a}$ & $\mathbf{1 3 . 5} \mathbf{a}$ & $3.5 \mathrm{a}$ \\
& $\mathrm{NaCl}$ & $\mathbf{0 . 7} \mathbf{a}$ & $\mathbf{1 . 4 9} \mathbf{a}$ & $\mathbf{0 . 0 7} \mathbf{a}$ & $0.14 \mathrm{ab}$ & $0.08 \mathrm{c}$ & $7.2 \mathrm{ab}$ & $2.5 \mathrm{a}$ & $64 \mathrm{a}$ & $12.5 \mathrm{ab}$ & $4.39 \mathrm{a}$ \\
\hline \multirow{2}{*}{ control } & Without & $0.13 \mathrm{~b}$ & $1.43 \mathrm{a}$ & $0.02 \mathrm{c}$ & $0.16 \mathrm{a}$ & $0.09 \mathrm{bc}$ & $8.7 \mathrm{ab}$ & $1.8 \mathrm{a}$ & $53 \mathrm{a}$ & $12 \mathrm{bc}$ & $3.32 \mathrm{a}$ \\
& $\mathrm{NaCl}$ & $0.11 \mathrm{~b}$ & $1.22 \mathrm{~b}$ & $\mathbf{0 . 0 4} \mathbf{b}$ & $0.12 \mathrm{~b}$ & $0.05 \mathrm{c}$ & $24 \mathrm{a}$ & $8.4 \mathrm{a}$ & $0 \mathrm{a}$ & $11 \mathrm{~b}$ & $4.9 \mathrm{a}$ \\
\hline
\end{tabular}

Values with same letters do not show statistically significant differences, $p \geq 0.05$, and in bold, are indicated the maximum and minimum statistically significant differences.

\subsubsection{Leaves}

In Table 7 are shown the results obtained from the essential macro-elements in the leaves of plants under both conditions. In plants that were subjected to salinity stress, an increase in the concentration of $\mathrm{Na}$ was evidenced as well as a reduction in calcium, a fact that was mitigated with the application of $Q$ product. An increase in $\mathrm{P}$ and Mn content was also found with the same treatment. Regarding iodine accumulation, the highest concentrations were found with the application of both sources of iodine under salinity stress compared to both controls.

Table 7. Effect of iodine-based products on minerals content in leaves, with and without salt stress.

\begin{tabular}{|c|c|c|c|c|c|c|c|c|c|c|c|}
\hline & \multirow[b]{2}{*}{ Stress } & \multicolumn{5}{|c|}{ Macroelements (\%) } & \multicolumn{5}{|c|}{ Microelements (ppm) } \\
\hline & & $\mathbf{P}$ & $\mathbf{K}$ & $\mathbf{N a}$ & Mg & $\mathrm{Ca}$ & Zn & $\mathrm{Cu}$ & $\mathrm{Fe}$ & Mn & I \\
\hline \multirow{2}{*}{ Q } & Without & $0.26 \mathrm{bc}$ & $1.34 \mathrm{a}$ & $0.02 \mathrm{~b}$ & $0.35 \mathrm{a}$ & $0.9 \mathrm{bc}$ & $20 \mathrm{a}$ & $11 \mathrm{a}$ & $200 \mathrm{a}$ & $45 \mathrm{bc}$ & $17.58 \mathrm{a}$ \\
\hline & $\mathrm{NaCl}$ & $0.59 \mathrm{a}$ & $1.43 \mathrm{a}$ & $0.05 a$ & $0.44 \mathrm{a}$ & $1 \mathrm{ab}$ & $20 \mathrm{a}$ & $12.5 \mathrm{a}$ & $100 \mathrm{a}$ & $100 \mathrm{a}$ & $17.95 \mathrm{a}$ \\
\hline \multirow{2}{*}{$\mathrm{KIO}_{3}$} & Without & $0.46 \mathrm{ab}$ & $1.32 \mathrm{a}$ & $0.01 \mathrm{~b}$ & $0.33 \mathrm{a}$ & $0.78 \mathrm{c}$ & $8.4 \mathrm{a}$ & $12 \mathrm{a}$ & $29 a$ & $36 c$ & $14.10 \mathrm{~b}$ \\
\hline & $\mathrm{NaCl}$ & $0.40 \mathrm{bc}$ & $1.31 \mathrm{a}$ & 0.04 a & $0.37 \mathrm{a}$ & $0.86 \mathrm{bc}$ & 15 a & $13 \mathrm{a}$ & $100 \mathrm{a}$ & $47 \mathrm{ab}$ & $17.65 \mathrm{a}$ \\
\hline \multirow{2}{*}{ control } & Without & $0.25 \mathrm{bc}$ & $1.45 \mathrm{a}$ & $0.03 \mathrm{~b}$ & $0.42 \mathrm{a}$ & $1.13 \mathrm{a}$ & $11 \mathrm{a}$ & $14 \mathrm{a}$ & $100 \mathrm{a}$ & $42 \mathrm{bc}$ & $6.28 \mathrm{~b}$ \\
\hline & $\mathrm{NaCl}$ & $0.1 \mathrm{c}$ & $1.37 \mathrm{a}$ & 0.04 a & $0.36 \mathrm{a}$ & $0.83 \mathrm{c}$ & $11 \mathrm{a}$ & $10 \mathrm{a}$ & $22 \mathrm{a}$ & $40 \mathrm{bc}$ & $14.6 \mathrm{~b}$ \\
\hline
\end{tabular}

Values with same letter do not present statistical differences, $p>0.05$, and in bold, are indicated the maximum and minimum statistically significant differences.

\subsection{Production and Fruit Quality}

In Table 8 are shown the results of yield and fruit quality in plants under both conditions, and an enhancement in yield was evidenced with $Q$ products application under salt stress. Additionally, an increase in firmness and a reduction in the loss of firmness were found with the application $\mathrm{KIO}_{3}$ without salt stress.

Table 8. Effect of iodine-based products on fruit quality and yield.

\begin{tabular}{cccccc}
\hline & Stress & Yield (g) & Brix & $\begin{array}{c}\text { Firmness } \\
\left.\mathbf{( k g ~ c m}^{-1}\right)\end{array}$ & $\begin{array}{c}\text { \% loss } \\
\text { Firmness }\end{array}$ \\
\hline \multirow{2}{*}{$\mathrm{Q}$} & Without & $260.6 \mathrm{a}$ & $5.41 \mathrm{~b}$ & $6.78 \mathrm{ab}$ & $80.11 \mathrm{a}$ \\
& $\mathrm{NaCl}$ & $\mathbf{2 2 7 . 3 5} \mathrm{a}$ & $5.78 \mathrm{ab}$ & $4.52 \mathrm{c}$ & $\mathbf{5 8 . 6 4} \mathbf{b}$ \\
$\mathrm{KIO}_{3}$ & Without & $262.3 \mathrm{a}$ & $5.92 \mathrm{ab}$ & $5.7 \mathrm{bc}$ & $81.46 \mathrm{a}$ \\
& $\mathrm{NaCl}$ & $140.37 \mathrm{~b}$ & $5.1 \mathrm{ab}$ & $\mathbf{8 . 0} \mathbf{a}$ & $85.89 \mathrm{a}$ \\
\multirow{2}{*}{ control } & Without & $233.26 \mathrm{a}$ & $5.3 \mathrm{~b}$ & $5.74 \mathrm{bc}$ & $88.11 \mathrm{a}$ \\
& $\mathrm{NaCl}$ & $194.9 \mathrm{~b}$ & $6.5 \mathrm{a}$ & $6.4 \mathrm{bc}$ & $73.31 \mathrm{a}$ \\
\hline
\end{tabular}

Values with same letter do not present statistical differences, $p>0.05$, and in bold, are indicated the maximum and minimum statistically significant differences. 


\subsection{Multivariate Analysis}

Multiple Lineal Regression: Pearson Correlation

A multiple linear regression was performed, using the Pearson correlation to observe the relationships between variables (see Table 9), and among the highlights a significant correlation was found between antioxidant potential and ascorbic acid concentration (0.6), superoxide dismutase activity (0.9), glutathione peroxidase (0.8), and reduced glutathione (0.7).

Table 9. Comparation between traits using multiple linear regression and Pearson coefficients.

\begin{tabular}{|c|c|c|c|c|c|c|c|c|c|c|c|c|c|c|c|c|c|c|}
\hline & Prot & SOD & CAT & APX & Anthocy & GSH & PA & $\mathbf{P}$ & $\mathbf{K}$ & $\mathrm{Ca}$ & Mg & $\mathbf{N a}$ & $\mathrm{Fe}$ & Mn & I & FWT & DWT & Yield \\
\hline asa & 0.4 & 0.8 & 0.60 & 0.1 & 0.9 & 0.5 & 0.6 & 0.5 & 0.5 & 0.1 & 0.4 & 0.3 & 0.3 & 0.5 & 0.2 & 0.2 & 0.3 & 0.2 \\
\hline prot & 1 & 0.1 & 0.1 & 0.1 & 0.6 & 0.9 & 0.5 & 0.3 & 0.1 & 0.4 & 0.1 & 0.9 & 0.7 & 0.1 & 0.3 & 0.6 & 0.6 & 0.7 \\
\hline phe & 1 & 0.3 & 0.1 & 0.9 & 0.3 & 0.3 & 0.5 & 0.3 & 0.1 & 0.3 & 0.1 & 0.1 & 0.1 & 0.9 & 0.9 & 0.8 & 0.9 & 0.7 \\
\hline SOD & -0.8 & 1 & 0.1 & 0.1 & 0.8 & 0.4 & 0.9 & 0.6 & 0.4 & 0.4 & 0.1 & 0.6 & 0.7 & 0.2 & 0.9 & 0.8 & 0.9 & 0.6 \\
\hline APX & -0.4 & 0.5 & 0.1 & 1 & 0.9 & 0.9 & 0.2 & 0.2 & 0.5 & 0.5 & 0.2 & 0.1 & 0.6 & 0.9 & 0.1 & 0.1 & 0.1 & 0.7 \\
\hline CAT & -0.5 & 0.7 & 1 & 0.5 & 0.9 & 0.8 & 0.2 & 0.2 & 0.7 & 0.9 & 0.1 & 0.1 & 0.3 & 0.6 & 0.6 & 0.1 & 0.1 & 0.7 \\
\hline GPX & -0.2 & 0.2 & 0.1 & -0.3 & 0.3 & 0.2 & 0.8 & 0.7 & 0.9 & 0.8 & 0.9 & 0.8 & 0.8 & 0.8 & 0.9 & 0.5 & 0.2 & 0.3 \\
\hline GSH & -0.1 & -0.2 & -0.1 & 0.1 & 0.9 & 1 & 0.7 & 0.7 & 0.6 & 0.6 & 0.9 & 0.1 & 0.9 & 0.9 & 0.9 & 1 & 0.7 & 0.1 \\
\hline Antoc & -0.1 & 0.1 & 0.1 & -0.1 & 1 & 0.1 & 0.5 & 0.3 & 0.5 & 0.4 & 0.4 & 0.8 & 0.2 & 0.5 & 0.9 & 0.2 & 0.6 & 0.40 \\
\hline PA & 0.1 & 0.1 & -0.2 & -0.1 & -0.1 & -0.1 & 1 & 0.5 & 0.8 & 0.8 & 0.5 & 0.3 & 0.3 & 0.8 & 0.9 & 0.8 & 0.8 & 0.1 \\
\hline
\end{tabular}

In bold are indicated the values highly correlated.

Additionally, a correlation was found between iodine and total phenolic compounds (0.9), superoxide dismutase (0.9), glutathione peroxidase (0.9), and reduced glutathione $(0.9)$, total anthocyanins $(0.9)$ and antioxidant potential $(0.9)$. The variables correlating with both dry and fresh weight and yield were total proteins, phenolic compounds and enzymes with antioxidant activity.

\subsection{Principal Components Analysis (PCA)}

The multivariate analysis of principal components evidenced that $58.7 \%$ of variance was explained by two principal components, and as can be observed in Figure 3 there is a positive correlation between the content of phenolic compounds, the activity of SOD, potassium, magnesium, calcium, manganese and yield with $\mathrm{Q}$ treatment under stress conditions, compared to tendency of control plants $(\mathrm{NaCl})$.

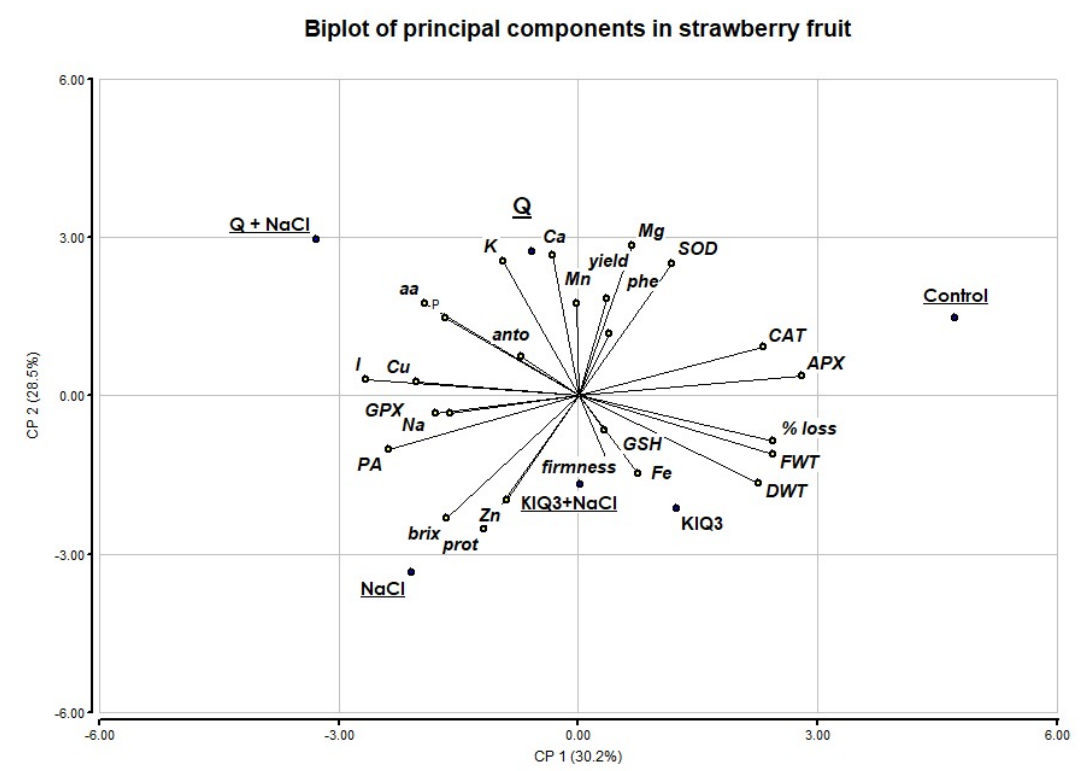

Figure 3. Biplot of parameters of antioxidants, elements, quality, growth and yield in strawberry fruit, under both conditions. 
In addition, a positive correlation was found between the enzymatic activity of ascorbate peroxidase, catalase, reduced glutathione, fresh and dry weight, and \% loss of firmness with the application of the $\mathrm{KIO}_{3}$ treatment, under stress conditions, compared to control plants $(\mathrm{NaCl})$.

Through this multivariate analysis, no difference in tendency was found between treatments and control under normal conditions.

\section{Discussion}

One strong piece of evidence to define stress condition is plant biomass and yield [31]. In the present research, it was found that the application of iodine-based products does not modify the growth of plants under normal conditions, but neither does it prevent the reduction of biomass under salt stress conditions. However, the yield, quality and nutraceutical value of strawberry fruits were improved.

Regarding the quality and nutraceutical value of the fruits, under normal conditions an increase in the concentration of non-enzymatic antioxidants such as phenolic compounds was found after the application of $Q$ products, where free iodine is the active principle. Similar results were found in the content of total phenolic compounds with the foliar application of $\mathrm{KIO}_{3}$ at $<80 \mu \mathrm{M}$ in basil [32] and lettuce [33] plants, arguing for a possible enhancement in the synthesis of the main enzymes of the shikimate pathway and phenylpropanoids, shikimate dehydrogenase (SKDH) and phenylalanine ammonium lyase (PAL). Additionally, the increase in these compounds was correlated with photoprotection in photosynthetic pigments due to their antioxidant activity, a case similar to the present research, where an increase in chlorophyll $a$ and $b$ was evidenced.

However, with this same treatment, a reduction in total protein content as well as in GPX activity was also found. Despite that many examples exist in the literature of iodine application in plants associated with an improvement or maintenance in nutritional quality parameters, negative effects have also been reported in the concentration of bioactive compounds. An example of this was an experiment carried out with lettuce grown in hydroponics, where the application of $\mathrm{KI}$ at $80 \mu \mathrm{M}$ led to a reduction in the activity of SOD [34], mainly due to the chemical species that is applied and, therefore, the oxidoreductive effect on the different metabolites [35]. The only constant in the application of the different chemical forms of iodine and its impact on the metabolic machinery this change. Gradually, adequate concentrations have been elucidated, depending on the culture and doses.

In leaves treated with $Q$ products, an increase in chlorophyll $a, b$ and total was evidenced, as well as a reduction in total phenolic compounds in the plants that were treated with $\mathrm{KIO}_{3}$. The yield and vigor of plants are highly dependent on photosynthesis, so the chlorophyll content is an indicator of the photosynthetic capacity of plants. Several studies have evaluated the impact of the application of iodine on this indicator. An example of this was reported in pepper, where after the application of low doses of $\mathrm{I}^{-}$, an increase in Chlo a was found, and, at high iodine concentrations, a decrease occurred coupled with a reduction in biomass [36], Wang et al. (2008) [37] in an experiment with cabbage concluded that, after absorption and transport via phloem of iodine, this is selectively stored in the chloroplasts of the leaves. The same author [38] in another experiment carried out with different horticultural species argues that this is due to a balance between cations, mainly $\mathrm{K}$, which is required for electrical balance in the production of ATP in chloroplasts and anions, which, if iodine is present, will compete with other anions to join the redox reaction.

Several studies have concluded that, as a consequence of salt stress, an overproduction of reactive oxygen species (ROS), such as superoxide $\left(\mathrm{O}_{2}\right)$, peroxide $\left(\mathrm{H}_{2} \mathrm{O}_{2}\right)$ and hydroxyl $\left(\mathrm{OH}^{-}\right)$, occurs, which lead to an imbalance in redox metabolism [39]. Among the defense mechanisms that plants use to face this oxidative stress is the synthesis of enzymatic antioxidants, which enter the primary defense line, such as superoxide dismutase, catalase, ascorbate and glutathione peroxidase, peroxide being the substrate of the last three. There is also a wide arsenal of non-enzymatic antioxidants such as glutathione, ascorbate, and 
phenolic compounds, among other molecules with reducing power [40]. In the present research, it was found that under stress conditions with $Q$ products applications, the activity of ascorbate peroxidase and catalase increased, as well as the concentration of reduced glutathione in the fruits, and a reduction in GPX activity was also found with the application of $\mathrm{KIO}_{3}$. Similar results were found by [41], where the authors argue that the application of iodine produces a possible modification in the Halliwell-Asada cycle.

In the leaves under stress conditions, a reduction in the content of GSH was evidenced with the application of $\mathrm{Q}$ products, as well as of total phenolic compounds in the plants treated with $\mathrm{KIO}_{3}$. As previously described, the hypothesis of the mechanism by which bioactive compounds are affected is directly related to the chemical species applied; however, with respect to GSH, it is worth mentioning that it is a tripeptide which is constantly changing its oxidized form; glutathione disulfide (GSSH) both maintains the redox status in the cell, and reduces to GSH through the catalysis of the enzyme glutathione reductase (GR) in the presence of NADPH [42]. On the one hand, the iodine accumulated can act as a bio-stimulant in the synthesis of antioxidants or act as electron donor directly. This can also be observed in the multiple linear regression analysis where iodine has a positive correlation with antioxidant potential, GSH, GPX activity and total phenolic compounds. Therefore, to gain a bigger picture, the quantification of the main antioxidant molecules such as those mentioned above must be extended over different periods of time, which in turn increases the cost and complexity of the metabolomic analysis.

Additionally, in leaves after the application of $\mathrm{KIO}_{3}$ an increase in ascorbic acid was found, a result similar to that reported in an experiment carried out in strawberry plants, where applying concentrations $>4 \mu \mathrm{M}$ of $\mathrm{KIO}_{3}$ ascorbic acid showed the same tendency. However, at higher concentrations the result was the opposite [43].

It has been widely reported that the exogenous application of iodine not only impacts the metabolomic part, but also the ionomic system, causing beneficial effects such as cooperation in the absorption and accumulation of other elements, as well as adverse effects such as antagonism to essential minerals.

In the present research, a strong impact on the concentration of essential minerals was found, for example, in fruits under normal conditions, an increase in the concentration of calcium and manganese, while in the leaves an increase was found only in calcium with the application of $Q$ products. Similar results were obtained in an experiment carried out on lettuce with two iodine application forms (soil and foliar), different chemical species ( $\mathrm{KI}$ and $\mathrm{KIO}_{3}$ ) and different doses; an increase in the concentration of $\mathrm{K}, \mathrm{Mg}$, $\mathrm{Ca}$ and $\mathrm{Mn}$ was found, regardless of the application method, dose or chemical species [44], indirectly supporting the hypothesis that iodine application at low concentrations has a positive influence on plants. The same author, in a similar experiment carried out in carrots, showed different elemental relationships arguing for differences related to plant species [45].

Under stress conditions, an increase in calcium, magnesium and potassium was found in fruits with the application of $Q$ products, evidenced by both statistical analysis (Anova one way), as well as multivariate analysis of principal components, while in the leaves an increase in manganese, calcium and phosphorus was found, with no evidence of the reduction of any essential element.

This phenomenon has been previously reported, but is not a fully understood mechanism. An example is [46], where an increase in macro-elements after the application of $\mathrm{KIO}_{3}$ in nopal was found. On the other hand, antagonistic effects have also been found on the concentration of essential elements in species such as lettuce [47]. This has been partly explained by the effect on the redox potential (Eh) and on the hydrogen potential $(\mathrm{pH})$ during the absorption, mobilization and chemical speciation of iodine in the surrounding environment [48,49]. Ashworth et al. (2006) and Medrano Macías et al. (2016) [50,51] indicated that a change in the redox state from $\mathrm{I}^{-}$to $\mathrm{I}_{2}$ produces a potential of $-535 \mathrm{~V}$, and probably $\mathrm{KIO}_{3}$ can provide a similar effect, thus modifying the bioavailability of other elements. 
It has also been shown in aquatic organisms that the absorption of iodine is carried out by $\mathrm{Cu}$-dependent enzymes, so by increasing the concentration of these elements, the activity of that enzyme increases, which will lead to an increase in the uptake of $\mathrm{Cu}$, and possibly the same occurs with other Mn or Fe-dependent enzymes [52].

The complexity of the ionomic interaction is very high, so further studies on the use and application of iodine will be decisive, with the aim of not affecting essential nutritional requirements, especially when the plants are grown in soil, or of establishing a way to achieve improvement in the absorption of essential minerals.

\section{Conclusions}

1. The application of iodine-based products did not modify the growth of strawberry plants under normal conditions. However, stress yield and fruit quality were improved with iodine-based products.

2. Some enzymatic and non-enzymatic antioxidants were increased with the application of iodine-based products in both leaves and fruits.

3. Both under normal conditions and under salinity stress, synergy with essential elements was found in leaves and fruits treated with iodine-based products.

4. The accumulation of iodine in leaves was increased with both iodine treatments under salt stress conditions.

Author Contributions: Conceptualization, J.M.M. and P.M.L.; Methodology, J.M.M., M.G.L.C. and P.M.L.; Software, W.A.N.O.; Validation, J.M.M., E.N.R.M. and A.B.M.; Formal Analysis, J.M.M.; Investigation, M.G.L.C.; Resources, P.M.L.; Data Curation, W.A.N.O.; Writing-Original Draft Preparation, J.M.M.; Writing-Review \& Editing, A.B.M., W.A.N.O. and E.N.R.M.; Visualization, A.B.M.; Supervision, J.M.M.; Project Administration, J.M.M.; Funding Acquisition, P.M.L. All authors have read and agreed to the published version of the manuscript.

Funding: This research received no external funding.

Institutional Review Board Statement: Not applicable.

Informed Consent Statement: Not applicable.

Data Availability Statement: The data presented in this study are available on request from the corresponding author.

Acknowledgments: The authors wish to thank the Quimcasa for technical support, also Hortensia Ortega Ortiz for her collaboration in the quantification of essential minerals in the Centro de Investigación en Química Aplicada and finally we wish to thank QFB. Estibaliz Torres Villarreal for her collaboration in translation of present paper.

Conflicts of Interest: The authors declare no conflict of interest. Any role of the funding sponsors in the choice of research project; design of the study; in the collection, analyses or interpretation of data; in the writing of the manuscript.

\section{References}

1. Gonzali, S.; Kiferle, C.; Perata, P. Iodine biofortification of crops: Agronomic biofortification, metabolic engineering and iodine bioavailability. Curr. Opin. Biotechnol. 2017, 44, 16-26. [CrossRef]

2. Venturi, S. Evolutionary Significance of Iodine. Curr. Chem. Biol. 2011, 5, 155-162. [CrossRef]

3. Küpper, F.C.; Carrano, C.J. Key aspects of the iodine metabolism in brown algae: A brief critical review. Metallomic 2019, 11, 756-764. [CrossRef] [PubMed]

4. Medrano-Macías, J.; Leija-Martínez, P.; Juárez-Maldonado, A.; Rocha-Estrada, A.; Benavides-Mendoza, A. Efecto de la aplicación de yodo sobre antioxidantes en plántulas de jitomate. Rev. Chapingo Ser. Hortic. 2016, 22, 133-143. [CrossRef]

5. Smoleń, S.; Kowalska, I.; Sady, W. Assessment of biofortification with iodine and selenium of lettuce cultivated in the NFT hydroponic system. Sci. Hortic. 2014, 166, 9-16. [CrossRef]

6. Kiferle, C.; Ascrizzi, R.; Martinelli, M.; Gonzali, S.; Mariotti, L.; Pistelli, L.; Flamini, G.; Perata, P. Correction: Effect of Iodine treatments on Ocimum basilicum L.: Biofortification, phenolics production and essential oil composition. PLoS ONE 2020, 15, e0229016. [CrossRef] [PubMed]

7. Li, R.; Li, D.-W.; Liu, H.-P.; Hong, C.-L.; Song, M.-Y.; Dai, Z.-X.; Liu, J.-W.; Zhou, J.; Weng, H.-X. Enhancing iodine content and fruit quality of pepper (Capsicum annuum L.) through biofortification. Sci. Hortic. 2017, 214, 165-173. [CrossRef] 
8. Cakmak, I.; Prom-U.-Thai, C.; Guilherme, L.R.G.; Rashid, A.; Hora, K.H.; Yazici, A.; Savasli, E.; Kalayci, M.; Tutus, Y.; Phuphong, P.; et al. Iodine biofortification of wheat, rice and maize through fertilizer strategy. Plant. Soil 2017, 418, 319-335. [CrossRef]

9. Halka, M.; Smoleń, S.; Ledwożyw-Smoleń, I.; Sady, W. Iodosalicylates and iodobenzoates supplied to tomato plants affect the antioxidative and sugar metabolism differently than potassium iodide. Folia Hortic. 2019, 31, 385-400. [CrossRef]

10. Gupta, N.; Bajpai, M.; Majumdar, R.; Mishra, P. Response of iodine on antioxidant levels of Glycine max L. Grown under Cd2+ stress. Adv. Biol. Res. 2015, 9, 40-48. [CrossRef]

11. Wu, F.; Guan, Z.; Coronado, J.J.A.; Garcia-Nazariega, M. An Overview of Strawberry Production in Mexico. EDIS 2018, $2018,5$. [CrossRef]

12. Acosta-Motos, J.R.; Ortuño, M.F.; Bernal-Vicente, A.; Diaz-Vivancos, P.; Sanchez-Blanco, M.J.; Hernandez, J.A. Plant Responses to Salt Stress: Adaptive Mechanisms. Agronomy 2017, 7, 18. [CrossRef]

13. Parihar, P.; Singh, S.; Singh, R.; Singh, V.P.; Prasad, S.M. Effect of salinity stress on plants and its tolerance strategies: A review. Environ. Sci. Pollut. Res. 2015, 22, 4056-4075. [CrossRef]

14. Crizel, R.; Perin, E.; Siebeneichler, T.; Borowski, J.; Messias, R.; Rombaldi, C.; Galli, V. Abscisic acid and stress induced by salt: Effect on the phenylpropanoid, L-ascorbic acid and abscisic acid metabolism of strawberry fruits. Plant. Physiol. Biochem. 2020, 152, 211-220. [CrossRef]

15. D'Anna, F.; Incalcaterra, G.; Moncada, A.; Miceli, A. Effects of different electrical conductivity levels on strawberry grown in soilless culture. ACTA Hortic. 2003, 609, 355-360. [CrossRef]

16. Steiner, A.A. A universal method for preparing nutrient solutions of a certain desired composition. Plant. Soil 1961, 15, 134-154. [CrossRef]

17. Ramos, S.; Faquin, V.; Guilherme, L.; Castro, E.; Ávila, F.; Carvalho, G.; Bastos, C.; Oliveira, C. Selenium biofortification and antioxidant activity in lettuce plants fed with selenate and selenite. Plant. Soil Environ. 2010, 56, 584-588. [CrossRef]

18. Nour, V.; Trandafir, I.; Ionica, M.E. HPLC organic acid analysis in different citrus juices under reversed phase conditions. Not. Bot. Horti Agrobot. Cluj-Napoca 2010, 38, 44-48. [CrossRef]

19. Yu, Z.; Dahlgren, R.A. Evaluation of Methods for Measuring Polyphenols in Conifer Foliage. J. Chem. Ecol. 2000, 26, 2119-2140. [CrossRef]

20. Cheng, Y.; Wei, H.; Sun, R.; Tian, Z.; Zheng, X. Rapid method for protein quantitation by Bradford assay after elimination of the interference of polysorbate 80. Anal. Biochem. 2016, 494, 37-39. [CrossRef] [PubMed]

21. Nakano, Y.; Asada, K. Hydrogen peroxide is scarvenged by ascorbate-specific peroxidase in spinach chloroplasts. Plant Cell Physiol. 1981, 22, 867-880.

22. Cansev, A.; Gulen, H.; Eris, A. The activities of catalase and ascorbate peroxidase in olive (Olea europaea L. cv. Gemlik) under low temperature stress. Hortic. Environ. Biotechnol. 2011, 52, 113-120. [CrossRef]

23. Flohé, L.; Günzler, W.A. Assays of glutathione peroxidase. Methods Enzymol. 1984, 105, 114-120. [CrossRef]

24. Xue, T.; Hartikainen, H.; Piironen, V. Antioxidative and growth-promoting effect of selenium on senescing lettuce. Plant. Soil 2001, 237, 55-61. [CrossRef]

25. Sahoo, S.; Prakash-Awasthi, J.; Sunkar, R.; Kumar Panda, S. Methods Molecular Biology. In Determining Glutathione Levels in Plants; Sunkar, R., Ed.; Humana Press: New York, NY, USA, 2017; pp. 273-277.

26. Atanacković, M.; Cvejić, J.; Gojković-Bukarica, L.; Veljović, M.; Despotović, S.; Pecić, S.; Gaćeša, B.; Leskošek-Čukalović, I. Quantitative determination of total anthocyanins and flavonoids in natural products obtained from grapes and malt. In Proceedings of the 6th Central European Congress on Food (CEFood 2012), Novi Sad, Serbia, 23-26 May 2012; pp. 183-188.

27. Munira, S.; Hossain, M.M.; Zakaria, M.; Ahmed, J.U.; Islam, M.M. Evaluation of Potato Varieties against Salinity Stress in Bangladesh. Int. J. Plant. Soil Sci. 2015, 6, 73-81. [CrossRef]

28. AOAC. Official Methods of Analysis of the Association of Official Analytical Chemists, 15th ed.; Association of official Analytical Chemist: Washington, DC, USA, 1990.

29. Patel, S.P.; Patel, M.A.; Modi, H.R.; Katyare, S.S. Improved method for estimation of inorganic phosphate: Implications for its application in enzyme assays. Indian J. Biochem. Biophys. 2007, 44, 88-93. [PubMed]

30. Ujowundu, C.O.; Ukoha, A.I.; Agha, N.C.; Nwachukwu, N.; Igwe, K.O. Iodine Biofortification of Selected Plants Using Potassium Iodide. Niger. J. Biochem. Mol. Biol. 2009, 24, 17-21.

31. Eggink, L.L.; LoBrutto, R.; Brune, D.C.; Brusslan, J.; Yamasato, A.; Tanaka, A.; Hoober, J.K. Synthesis of chlorophyll b: Localization of chlorophyllide a oxygenase and discovery of a stable radical in the catalytic subunit. BMC Plant. Biol. 2004, 4, 5. [CrossRef] [PubMed]

32. Puccinelli, M.; Pezzarossa, B.; Rosellini, I.; Malorgio, F. Selenium Enrichment Enhances the Quality and Shelf Life of Basil Leaves. Plants 2020, 9, 801. [CrossRef] [PubMed]

33. Blasco, B.; Rios, J.J.; Leyva, R.; Cervilla, L.M.; Sánchez-Rodríguez, E.; Rubio-Wilhelmi, M.M.; Rosales, M. Ángel; Ruiz, J.M.; Romero, L. Does Iodine Biofortification Affect Oxidative Metabolism in Lettuce Plants? Biol. Trace Elem. Res. 2010, 142, 831-842. [CrossRef]

34. Blasco, B.; Rios, J.J.; Cervilla, L.M.; Sánchez-Rodríguez, E.; Rubio-Wilhelmi, M.M.; Rosales, M.A.; Ruiz, J.M.; Romero, L. Photorespiration Process and Nitrogen Metabolism in Lettuce Plants (Lactuca sativa L.): Induced Changes in Response to Iodine Biofortification. J. Plant. Growth Regul. 2010, 29, 477-486. [CrossRef] 
35. Krzepiłko, A.; Prażak, R.; Skwaryło-Bednarz, B.; Molas, J. Agronomic biofortification as a means of enriching plant foodstuffs with iodine. ACTA Agrobot. 2019, 72, 1-9. [CrossRef]

36. Li, Z.; Liang, D.; Peng, Q.; Cui, Z.; Huang, J.; Lin, Z. Interaction between selenium and soil organic matter and its impact on soil selenium bioavailability: A review. Geoderma 2017, 295, 69-79. [CrossRef]

37. Weng, H.-X.; Hong, C.-L.; Yan, A.-L.; Pan, L.-H.; Qin, Y.-C.; Bao, L.-T.; Xie, L.-L. Mechanism of Iodine Uptake by Cabbage: Effects of Iodine Species and Where It is Stored. Biol. Trace Elem. Res. 2008, 125, 59-71. [CrossRef] [PubMed]

38. Weng, H.-X.; Weng, J.-K.; Yan, A.-L.; Hong, C.-L.; Yong, W.-B.; Qin, Y.-C. Increment of Iodine Content in Vegetable Plants by Applying Iodized Fertilizer and the Residual Characteristics of Iodine in Soil. Biol. Trace Elem. Res. 2008, 123, 218-228. [CrossRef]

39. Hasegawa, P.M.; Bressan, R.A.; Zhu, J.-K.; Bohnert, H.J. Plantcellular and molecularresponses tohighsalinity. Annu. Rev. Plant. Biol. 2000, 51, 463-499. [CrossRef]

40. Choudhury, F.; Rivero, R.; Blumwald, E.; Mittler, R. Reactive oxygen species, abiotic stress and stress combination-Choudhury. Plant J. 2017. [CrossRef]

41. Leyva, R.; Sánchez-Rodríguez, E.; Ríos, J.J.; Rubio-Wilhelmi, M.M.; Romero, L.; Ruiz, J.M.; Blasco, B. Beneficial effects of exogenous iodine in lettuce plants subjected to salinity stress. Plant. Sci. 2011, 181, 195-202. [CrossRef]

42. Zhou, Y.; Wen, Z.; Zhang, J.; Chen, X.; Cui, J.; Xu, W.; Liu, H.-Y. Exogenous glutathione alleviates salt-induced oxidative stress in tomato seedlings by regulating glutathione metabolism, redox status, and the antioxidant system. Sci. Hortic. 2017, 220, 90-101. [CrossRef]

43. Li, R.; Liu, H.-P.; Hong, C.-L.; Dai, Z.-X.; Liu, J.-W.; Zhou, J.; Hu, C.-Q.; Weng, H.-X. Iodide and iodate effects on the growth and fruit quality of strawberry. J. Sci. Food Agric. 2016, 97, 230-235. [CrossRef]

44. Smoleń, S.; Rożek, S.; Strzetelski, P.; Ledwożyw-Smoleń, I. Preliminary evaluation of the influence of soil fertilization and foliar nutrition with iodine on the efficiency of iodine biofortification and chemical composition of lettuce. J. Elem. 2011, 16, 613-622. [CrossRef]

45. Smoleń, S.; Sady, W.; Rożek, S.; Strzetelski, P.; Ledwożyw-Smoleń, I. Preliminary evaluation of the influence of iodine and nitrogen fertilization on the effectiveness of iodine biofortification and mineral composition of carrot storage roots. J. Elem. 2011, 16, 275-285. [CrossRef]

46. García Osuna, H.T.; Mendoza, A.B.; Morales, C.R.; Rubio, E.M.; Star, J.V.; Ruvalcaba, R.M.; Pakistan, L. Iodine application increased ascorbic acid content and modified the vascular tissue in Opuntia Ficus-Indica. J. Bot. 2014, 46, 127-134.

47. Smoleń, S.; Skoczylas, Ł.; Rakoczy, R.; Ledwożyw-Smolen, I.; Kopec, A.; Piatkowska, E.; Bieżanowska-Kopec, R.; Pysz, M.; Koronowicz, A.; Kapusta-Duch, J.; et al. Mineral composition of field-grown lettuce (Lactuca sativa L.) depending on the diversified fertilization with iodine and selenium compounds. ACTA Sci. Pol. Hortorum Cultus 2015, 14, 97-114.

48. Terzano, R.; Cesco, S.; Mimmo, T. Dynamics, thermodynamics and kinetics of exudates: Crucial issues in understanding rhizosphere processes. Plant. Soil 2015, 386, 399-406. [CrossRef]

49. Venturi, S.; Venturi, M. Evolution of Dietary Antioxidants: Role of Iodine. Tutto Sulla Nutr. 2007, 1-25.

50. Ashworth, D.; Shaw, G. Effects of moisture content and redox potential on in situ Kd values for radioiodine in soil. Sci. Total Environ. 2006, 359, 244-254. [CrossRef] [PubMed]

51. Medrano-Macías, J.; Leija-Martínez, P.; González-Morales, S.; Juárez-Maldonado, A.; Benavides-Mendoza, A. Use of Iodine to Biofortify and Promote Growth and Stress Tolerance in Crops. Front. Plant. Sci. 2016, 7, 1146. [CrossRef]

52. Shiroyama, K.; Kawasaki, Y.; Unno, Y.; Amachi, S. A putative multicopper oxidase, IoxA, is involved in iodide oxidation by Roseovarius sp. strain A-2. Biosci. Biotechnol. Biochem. 2015, 79, 1898-1905. [CrossRef] 